\title{
European Humanism and Benedictine Monasticism. Around Selected Statements of Benedict XVI
}

Contemporary Europe is marked by many contradictions. While we can see in it the real concern and fight for dignity and rights of every human being, Europe is also a witness to a hecatomb of millions of lives seen in history never before. They were victims of two world wars, Nazi and communist ideology, but also abortion clinics and drug addiction. This experience makes us aware that often at the beginning of these unimaginable tragedies of millions of Europeans, humiliated, abused, killed in Nazi extermination camps or Soviet gulags, there was a falsified, reduced, diminished by truly transcendental dimensions truth about man. Bad and reduced anthropology has such tragic consequences. In the face of these events, the Church at the Second Vatican Council in the constitution Gaudium et spes reminded that the whole truth about man was really only clarified in the mystery of the Incarnate Word. ${ }^{2}$ The great and inalienable mission of Christians in the modern world, especially in Europe, is the committed concern for integral humanism.

Joseph Ratzinger, already as a university professor and then a cardinal, addressed the problem of integral, Christian, Benedictine humanism in the context of the challenges of modern Europe. The results of his search were published,

\footnotetext{
${ }^{1}$ Rev. Pawel Kiejkowski - born in 1968, priest of the Archdiocese of Gniezno, Associate Professor ( $\mathrm{PhD}$ holding a post-doctoral degree) in the Division of Systematic Theology at the Faculty of Theology, Adam Mickiewicz University in Poznan; member of the Society of Dogmatic Theologians and the Society of Fundamental Theologians; special interests: theological anthropology, Orthodox thought; e-mail: pkiejkowski@wp.pl. ORCID: 0000-0003-0787-4395.

${ }^{2}$ See Vatican Councill II, Gaudium et spes, http://www.vatican.va/archive/hist_councils/ii_vatican_council/documents/vat-ii_const_19651207_gaudium-et-spes_en.html [accessed30.09.2020], 22.
} 
among others, in two books: The Time of Change in Europe ${ }^{3}$ and Europe of Benedict XVI in the Cultural Crisis. ${ }^{4}$ With great disappointment he accepted the refusal to mention Christian roots in the European constitution. ${ }^{5}$ Therefore, as the Pope, he placed the program of promoting integral humanism at the center of his Petrine ministry. He was convinced that at the beginning of the new millennium Europe needed the necessary ethical foundation. Christianity can provide inspirational help here not to give specific political hints or technical solutions, but to give objective moral principles, discovered by reason enlightened by faith. According to the retired Pope, modern times were marked by the dictatorship of rationalism, while the present day was marked by dictatorship of relativism. Both give inadequate answers to basic human questions about their identity. Rationalism has made the human reason the measure of everything, forgetting all its limitations. However,

Contemporary relativism humiliates reason as it actually goes so far as to assert that man cannot know anything with certainty outside the field of positive sciences. Nevertheless, today $[\ldots]$ a man 'begging for meaning and making a living: comes out to constantly search for comprehensive answers to the deep questions he poses. ${ }^{6}$

The European seeking the truth about his/her humanity will find it through faith in the incarnate Son. ${ }^{7}$

Georg Wiegel in his book Benedetto XVI. La scelta di Dio recalls the important intuition of the evangelical pastor Timothy George regarding the interpretation of the pontificate of the Pope from Bavaria. Commenting on the election of Joseph Ratzinger as the Pope, who takes the name of Benedict XVI, he wrote that Ratzinger revealed the clear will to continue the work of evangelization by promoting a new integral humanism. The starting point is not to be sociological analyzes or philosophical reflections, but the person of the incarnate Word. This is expressed by one of the maxims contained in the Rule of Saint Benedict: "never put anything above Christ's love". ${ }^{8}$ The primacy of Jesus Christ allowed

\footnotetext{
${ }^{3}$ See J. Ratzinger, Czas przemian w Europie. Miejsce Kościoła i świata, thum. M. Mijalska, Kraków 2005.

${ }^{4}$ See idem, Europa Benedykta w kryzysie kultur, thum. W. Dzieża, Częstochowa 2005.

${ }^{5}$ See E. Guerriero, Świadek prawdy. Biografia Benedykta XVI, tłum. J. Tomaszek, Kraków 2018, p. 462.

6 Bogaty wiara i czlowieczeństwem, „Przewodnik katolicki” 33 (2009), p. 27.

${ }^{7}$ See P. Kiejkowski, Czy nauka może zastapić wiarę? Relacja między wiara a nauka w tekstach Josepha Ratzingera (Benedykta XVI) [in:] Wiara pod lupq. Wspótczesne pytania o racjonalność wiary, red. R. Pietkiewicz, Wrocław 2014, pp. 165-166.

${ }^{8}$ See G. Weigel, Benedetto XVI. La scelta di Dio, Soveria Mannelli 2016, p. 209.
} 
the Benedictines to build real and life-giving humanism, based on the famous words: ora et labora. In this way, Benedictine monks laid the foundations for the European civilization, the traces of which are still present in its thoughts and culture. ${ }^{9}$ The legacy of the Benedictine, more monastic life that we find at the root of integral European humanism, the Pope pensioner has often shown as an inspirational key to overcoming the crisis that culture in Europe is experiencing today.

This study is only a small contribution to the presentation of the whole lifegiving link between European humanism and Benedictine monasticism. In the achievements of Pope Ratzinger we find many inspirational texts: for example, Wednesday catecheses devoted to the fathers and writers of the Middle Ages ${ }^{10}$, holy women, many of whom were nuns ${ }^{11}$, a Franciscan and Dominican ${ }^{12}$ saint, or homilies given during his pilgrimage to Monte Casino in 2009. ${ }^{13}$ Of these, I would like to discuss only two characteristic statements. The first will be the speech of Benedict XVI during a meeting with people active in culture at the Bernardine College in Paris on September 12, 2008. The second is the text Crisis of cultures, in which Abbot Benedict and his way of life were shown by the Pope pensioner as a proper response to the modern crisis of European humanism.

\section{The foundation of integral humanism is the search for God}

One of the most important speeches of the pontificate of Benedict XVI was the lecture presented during the meeting of the Pope with representatives of French culture at the College of Bernardines in Paris. It took place on September 12, 2008 during the papal pilgrimage on the $150^{\text {th }}$ anniversary of the revelations of the Blessed Virgin Mary in Lourdes. The college is located in a former Cistercian monastery, called Bernardine, in France. This name comes from the name of one of the most famous representatives of the Cistercian order, Saint Bernard of Clairvaux. The monks occupied the monastery buildings until 1790. Then, as a result of the French Revolution, the buildings were confiscated. In 2001, the Diocese of Paris bought them again, restored them and designated them as a meet-

\footnotetext{
${ }^{9}$ See P. Seewald, Benedykt XVI. Portret z bliska, thum. G. Popek, Kraków 2006, pp. 346-347.

${ }^{10}$ See Benedykt XVI, Mistrzowie duchowi. Ojcowie i pisarze średniowiecza, Poznań 2011 (translation after Polish version of L'Osservatore Romano).

${ }^{11}$ See Benedykt XVI, Mistrzynie duchowe, Poznań 2012 (translation after Polish version of L'Osservatore Romano).

${ }^{12}$ See Benedykt XVI, Mistrzowie franciszkańscy i dominikańscy, Poznań 2012 (translation after Polish version of L'Osservatore Romano).

${ }_{13}$ See Benedykt XVI, Niczego nie przedkładać nad mitość Chrystusa (Monte Casino 24 May 2009), „L'Osservatore Romano” (Polish edition) 9 (2008), pp. 52-53.
} 
ing place, as well as the Christian and cultural formation. ${ }^{14}$ One has to remember the circumstances of this meeting. The Church in France had been struggling with a serious crisis for a long time: the emptying and closing of churches, the decreasing number of baptisms and other sacraments, and the decreasing number of candidates preparing for priesthood and consecrated life. Simultaneously, traditionalist communities were developing quite dynamically. All this raised the anxiety of many representatives of the French episcopate. The Pope's visit was also accompanied by protests by avid defenders of the state's secularity opposing the state's papal rank.

At the beginning of his speech Benedict XVI pointed out that it would concern the beginnings of the Western Christian theological thought and the roots of European culture ${ }^{15}$ The meeting point itself - the Cistercian monastery - is significant and emblematic. From a historical perspective, the monasteries had become the places where treasures of ancient culture were preserved. At the same time, a new, already Christian, European culture was formed on their foundations. It happened during a period of rapid and profound cultural and social changes, which were caused by great migrations of people and the formation of new structures of medieval society. Meanwhile, it is true, the Pope notes, that the monks' fundamental desire was not to create a new culture or to store the treasures of ancient culture.

Motivation was much simpler. Their [the monks'] goal was to search for God, quaerere Deum. In the turmoil of those times, when it seemed that nothing could stand, the monks wanted the most important thing: to devote themselves to what is valuable, imperishable, to find Life itself. They were looking for God. ${ }^{16}$

Amid the diversity of everyday matters, the Benedictine monks wanted to find the most important and certain thing. Their lives had an 'eschatological' feature, not in a temporal sense, as an escape from the world or passive waiting for an imminent death, but in an existential sense: in the midst of what is temporal to look for the ultimate. The monks did not grope for God in the dark. They believed that God had revealed Himself for the good of people, He left signs in the created world on a path which He made for the man Himself. ${ }^{17}$ The monk's task was to find God's signs and to follow the trail. First of all, the Word was the way, which in the Scriptures was offered to humanity. Therefore, the culture of the word became a necessary condition for seeking God. God's desire was expressed in

${ }^{14}$ See E. Guerriero, Świadek prawdy..., pp. 468-469.

${ }^{15}$ See Benedykt XVI, Fundamentem prawdziwej kultury jest poszukiwanie Boga (Paris 12 September 2008), L'Osservatore Romano" (Polish edition) 10-11 (2008), p. 12.

${ }^{16}$ Benedykt XVI, Fundamentem prawdziwej kultury jest poszukiwanie Boga ..., p. 13.

${ }^{17}$ See A. Nichols, Myśl Benedykta XVI Wprowadzenie do myśli teologicznej Josepha Ratzinge$r a$, thum. D. Chabrajska, Kraków 2006, pp. 79-96. 
respect and in learning literary culture, learning the secrets of the language, its structures and applications. Through the word of the Bible, God Himself comes to the man, and man, by word goes, returns to Him. For this reason, the monastery school and library were an integral part of the monastery. It was first and foremost a school of service to the Lord, so that by training and educating the mind and erudition, the monk would gain the ability to see the one Word among many words.

Jesus Christ, the Word that opens the way to God and at the same time is the way, is also the Word that gives birth and strengthens the community. Jesus, opening people to God, opens them to others. The search for true life in God does not happen individually, in isolation from another one, but always in a community of faith. ${ }^{18}$ It engages the whole person in all aspects of his/her existence. On this pilgrim's journey, the Word gradually involves faithful disciples in dialogue with God, offering them words which they can address to Him. The Book of Psalms helps those who pray before God to express their life in all its complex reality; not only express, but also sing in the community of faith of people and in the face of angels (see Ps 138:1). It has become a necessary matter for Benedictine monks, as Benedict XVI emphasizes, to cultivate liturgical singing, caring especially for its harmony. Cacophony in singing was interpreted as great neglect in the service of the Lord. The lack of harmony was described as a departure to the land where everything is upside down (regio dissimilitudinis). St. Augustine used this term to describe the state of his lost soul before conversion: a man created in the image of God, through disorder, a cacophony of sin, abandons God and, as a consequence, goes to a land where everything is upside down. ${ }^{19}$ In the distance from God, man becomes increasingly unlike God, but also unlike his/her true human nature intended by the Creator. ${ }^{20}$ Therefore, through a patient study, daily prayer and harmonious singing, the monks wanted to answer the greatness of the Word entrusted to them in a dignified manner.

Christianity sees in its words the only Word, the Logos Himself, who reveals His secret through this multitude and realities of human history. This particular structure of the Bible is still a new challenge for every generation. By its nature, it excludes everything that is now called 'fundamentalism'. ${ }^{21}$

In the Rule of Saint Benedict next to the ora there is also the labora, as the second constitutive element of monastic life. In the Greek classical tradition, manual labor was considered to be a slave occupation. The Jewish tradition was

\footnotetext{
${ }^{18}$ See J. Szymik, Teologia Benedicta, t. 2, Katowice 2010, pp. 220-231.

${ }^{19}$ See Św. Augustyn, Wyznania, thum. Z. Kubiak, Kraków 2001, VII, 10.16.

${ }^{20}$ See Benedykt XVI, Fundamentem prawdziwej kultury jest poszukiwanie Boga..., p. 14.

${ }^{21}$ Ibidem, p. 15.
} 
different: rabbis were not only worshippers and scholars of the Bible, but also worked as craftsmen. The apostle Paul, as a rabbi and then a herald of the Gospel among the Gentiles, worked according to this pattern and worked physically for his own living, making tents. This tradition had an impact on monasticism, which equated manual work with prayer and study. Recognizing the eternity of matter, the Greek-Roman world did not know God the Creator. God could not 'get dirty' with matter. Creating and organizing the world was the work of a demiurge, a god of a lower rank. The God of the Bible is different again. He is the only God, living and true, Creator of all creation 'ex nihilo' who is still active in human history. ${ }^{22}$ Work creation is unfinished. The work of people appears as a special expression of the similarity to God who gives part in His creation. ${ }^{23}$ "Without this work culture, reminds the Pope, which makes up monasticism along with the culture of the word, the development of Europe, its ethos and the concept of the world would be unthinkable". ${ }^{24}$ Work as co-participation in the Creator's act appears as an adequate measure of man's creative involvement. When this measure is lacking, warns Benedict XVI at the same time, man elevates himself to the level of a deified creator, and transformation of the world according to his measure can lead to its destruction.

The search for God, quaerere Deum — is the basic attitude of a Christian monk. Thanks to the Word, it becomes a pilgrim's fascinating way of life. The discovery of this moving truth awakens in Christians the desire to share the discovered treasure (see Mt 13:45-46) and to pass on their faith (see 1 Cor 19:16). It is not propaganda that would aim to increase its number and influence, but an internal necessity that results from finding the true, only God, God the Father, who finally made himself known through His Son, bringing rational answers to the questions bothering every man.

The universality of God and the universality of reason open to His action were for them a motivation and at the same time a commitment to evangelization. According to them, faith was not dependent on cultural customs, different from one nation to another, but it was connected with the truth, which equally applies to every human being. ${ }^{25}$

An eloquent example of such evangelization is the speech of the apostle Paul at the Areopagus (see Acts 17:16-34). The Apostle of the Nations does not preach

${ }^{22}$ See Z.J. Kijas, Początki świata i czlowieka, Kraków 2004, pp. 126-137.

${ }^{23}$ See K. Wencel, Traktat o czlowieku [in:] Dogmatyka, red. A. Adamiak, A. Czaja, J. Majewski, t. 5, Warszawa 2007, pp. 21-23.

${ }^{24}$ Benedykt XVI, Fundamentem prawdziwej kultury jest poszukiwanie Boga ..., p. 16.

${ }^{25}$ Ibidem. 
unknown gods to Athenians. He foretells the one whom people do not know, but still they do know. God unknown and yet known. ${ }^{26}$ Man deepens his thoughts in a way, he knows that God must exist, and the source of everything that exists is not irrationality and chance, but personal, free Reason. God, who is the construct of people's thoughts, is not and cannot be the true God. The novelty of the Christian message is that the invisible and unknowable God has revealed himself because of man. The path to Him was opened by Himself. The Logos in His humility becomes a body, a human being, to be present in a human way among us. In order to be able to receive Him, man needs humility of mind and heart that respond to the humbleness of God.

To conclude, Benedict XVI argued that although today's European situation differed in many respects from that of ancient Jerusalem, Rome or Athens, there were also many analogies. For many Europeans, God has become a great unknown again. But just as in the ancient empire in many images of deities there was a question about the true, still unknown God, so today the absence of God silently disturbs the hearts of many with the question about Him. On the paths of modern creation of a real European culture, integral humanism, Christian quaerere Deum: the search for God who first found us and revealed Himself to us is still valid, moreover, it is necessary. "Purely positivist culture, warned the Pope, for whom the question of God would only belong to the field of subjectivism as unscientific, would be the surrender of reason, giving up its highest possibilities, and thus the failure of humanism, and with serious consequences". ${ }^{27}$ The search for God, the center of life for Benedictine monks, which has become a life-giving source for European culture, remains an indispensable condition and foundation for creating and developing true culture.

\section{The crisis of European culture and St. Benedict}

In 2005, the Polish translation of the Italian publication L'Europa di Benedetto nella crisi delle culture ${ }^{28}$ was published. The title itself is very significant. Europe is called Europe of Benedict. The Saint Abbot of Monte Casino, patriarch of Western monasticism, is therefore portrayed as one of the fathers of European culture, and, at the same time, as an appropriate proposition to overcome the deep crisis of this Europe. The book contains, inter alia, the text Crisis of Cultures ${ }^{29}$ that interests us. Contemporary Europe is witnessing scientific and technical achieve-

\footnotetext{
${ }^{26}$ See H. Bürkle, Człowiek w poszukiwaniu Boga, thum. M.E. Kowalska, Poznań 1998, pp. 33-37.

${ }^{27}$ Benedykt XVI, Fundamentem prawdziwej kultury jest poszukiwanie Boga ..., p. 16.

${ }^{28}$ See J. Ratzinger, Europa Benedykta...

${ }^{29}$ See ibidem, pp. 39-72.
} 
ments unprecedented in human history. They are a great opportunity and a threat to humanity. Simultaneously, they are a loud cry for responsibility towards the people of Europe and their culture. The threats are enormous, it is enough to mention terrorist groups that can reach access to nuclear or biological weapons at any time. ${ }^{30}$ Such a threat are possibilities of manipulating bigger and bigger social groups, acquired and constantly improved by specific power or business structures. Thanks to the great achievements of the sciences that deal with the broadly understood reality of man, he is able to 'build' or 'modify' himself. ${ }^{31}$ The human being no longer appears as a gift of the Creator but as a product of a human action, whose existence may depend on various criteria of his/her usefulness. "Hence, over this man there is no longer the splendor of his existence in the image of God, giving him dignity and inviolability, but only the power of human skills exists. Such a man is only an image of a man — but what kind of man?"32 The increase in human capabilities is not matched by the simultaneous development of his/her moral strength. Moral strength not only did not strengthen, but on the contrary, it decreased. Under the influence of positivist and technical mentality, which denies the possibility of learning objective moral values, it has passed into the subjective sphere.

Joseph Ratzinger considers this imbalance between technical possibilities and moral strength "the most serious danger of our time". ${ }^{33}$ The new morality proposed today to Europe, although it evokes the values that humanity needs, such as justice, peace, ecology, without objective values, it remains indefinite and shifts to the political and party sphere. It is presented primarily as a requirement directed at other people, and not as a personal duty of each person in his/her everyday life. Ethics so much misunderstood depends to a large extent on influence, power, profit and utility groups. As an example of such moralism, the German theologian cites pacifism of the seventies. Similarly, any attempt to build the 'Kingdom of God' should be interpreted by referring only to the 'value of the Kingdom', and bypassing God who is the subject and cause of that kingdom.

Joseph Ratzinger points to two fundamental foundations of modern Europe, which along with the importance of European culture have had a huge impact on the entire modern world. Christianity and scientific rationalism are these values. In Europe, Christianity has received its cultural and intellectual mark, becoming a humanizing ferment for all humanity. Currently, scientific rationalism leaves its ubiquitous mark all over the world, becoming the cause of its unification. And it was in this form of rationalism that "Europe developed a culture that,

\footnotetext{
${ }^{30}$ See idem, Czas przemian w Europie..., pp. 16-19.

31 See H. Seweryniak, Świadectwo $i$ sens, Płock 2001, pp. 77-78.

32 J. Ratzinger, Europa Benedykta ..., p. 42.

33 Ibidem, p. 43; see idem, Czas przemian w Europie..., pp. 23-25.
} 
in a way unknown to humanity, excluded God from public consciousness, both negating Him completely, as well as recognizing His existence as unprovable, uncertain, and therefore belonging to the scope of subjective choices, therefore not important for public life". ${ }^{44}$ This positivist mentality, guided by the principle of utility led to a real moral crisis. The objective category of moral good and evil has disappeared. This is a great European paradox. On the one hand, Christianity received its most fruitful form. Conversely, it was in Europe that a culture was created which is in total contradiction with Christianity and all religious and moral traditions of humanity. This situation calls for great responsibility to all Europeans.

The complexity of the crisis has been revealed by the issue of reference to God in the European constitution and the problem of mentioning Europe's Christian roots. Although various reasons were given not to do so, for example, not to offend the religious sensitivity of followers of Islam, Joseph Ratzinger shows that ultimately something more fundamental is at stake. The lack of reference to the Christian heritage in the description of European identity arises from the ideology that it can only be based on the radical atheistic Enlightenment culture ${ }^{35}$ Other religious cultures, above all Christianity, can coexist next to it only if they recognize the criteria of the Enlightenment culture and abide by it. Conversely, the culture of the Enlightenment is defined by the right to freedom as a basic value. The freedom of choice is an absolute value and a criterion for assessing other values. But in this perspective we are witnessing many contradictions, for example, between the desire for women's freedom and the right to life of unborn children. Recognizing the Enlightenment foundation as the only valid one leads (and it will increase) to discrimination against many Europeans on the basis of their religious and moral beliefs (for example, Christians' rights to moral assessment of homosexual acts will be questioned or the 'right' to priestly ordination for women will be required). "The confusing ideology of freedom leads to dogmatism, which turns out to be increasingly hostile to freedom". ${ }^{36}$ In addition, it is characteristic of the Enlightenment culture to glorify its universal claims and conviction of its perfection and self-sufficiency. It does not need and does not want other cultures, especially religious ones, and considers the existing ones, above all Christianity, to be dead. It is obvious to it that God does not exist and He cannot have anything to do with public life and with the foundations of the state and society. ${ }^{37}$

${ }^{34}$ Idem, Europa Benedykta..., p. 47.

${ }^{35}$ See R. Regoli, Benedykt XVI wielki papież czasu kryzysu, thum. K. Dyjas-Fezzi, Kraków 2017, pp. 307-314.

${ }^{36}$ J. Ratzinger, Europa Benedykta ..., p. 53.

${ }^{37}$ See R. Regoli, Benedykt XVI..., pp. 314-322. 
The German cardinal points out, however, that the Enlightenment culture, which is proper to our historical age, is neither completely rational as it mutilates and reduces the possibilities of the human reason to the positivist perspective, nor is it complete, because it does not reveal the full truth about man. It can be healed only by restoring its roots. ${ }^{38}$ The symptomatic separation of the preamble to the Constitution from Christian roots is not an expression of tolerance that apparently wants to respect all cultures, but is a testimony to the absolutization of thinking and life, which radically questions every other historical cultural experience of humanity. "The real contradiction of today's world lies not between various religious cultures, but between the radical liberation of man from dependence on God, from the roots of life on the one hand, and the great religious cultures on the other" ${ }^{39}$ It is an expression of the conflict between the radical emanation of man who wants to erase God from the public life of humanity, and His great cultural and religious heritage. One can see here the fruits of relativism, which, becoming dogmatism, usurps the right to the ultimate possession of reason and questions the value of any other cognitive experience. The only solution to this conflict, so as not to lose human dignity, is a return to the roots, to integral humanism, to God.

Christianity does not mean rejection of the Enlightenment. From the beginning, Joseph Ratzinger emphasizes, Christianity understood itself as religion of the Logos, religion according to the reason. ${ }^{40}$ It is also universal religion, often addressed to the persecuted, which by its nature does not want to be considered state religion in any state. And although over the centuries Christianity has unfortunately become religion of the state or tradition and the philosophical quest for truth has sometimes given up its mission dormant by theological theses, there is a deep correspondence between Christianity and the Enlightenment, which can lead to reconciliation between the Church and modernity, which is a great heritage that still needs protection. Both sides need mutual dialogue and conversion. The foundation of this meeting, believes the Pope pensioner, is the recognition that at the beginning of everything that exists there is the Logos, and therefore, the universe does not come from the irrational. The human reason is not a product of evolution. Because "...the reason that comes from the unreasonable and which at the end is unreasonable cannot be the solution to our problems. Only the creative reason revealed in crucified God as love, can actually show us the way". ${ }^{41}$ Simultaneously, Christians are obliged to a special responsibility for the truth and following the rational, responsibility for faith faithful to the creative Logos.

${ }^{38}$ J. Ratzinger, Czas przemian w Europie..., p. 30-34.

${ }^{39}$ Idem, Europa Benedykta ..., p. 62.

${ }^{40}$ See J. Szymik, Prawda i mąrość. Przewodnik po myśli Benedykta XVI, Kraków 2019, pp. 159-162.

${ }^{41}$ J. Ratzinger, Europa Benedykta ..., p. 67. 
The Enlightenment representatives, in turn, must admit that modern proposals of a common foundation, especially Kant's postulates of practical reason, turn out to be insufficient. And modern attempts to create human reality with the complete omission of God lead ever faster to the fall of man. Therefore, the atheistic axiom of the Enlightenment should be changed. Josef Ratzinger suggests that all Europeans, including non-believers, return to Pascal's assumption: try to live and lead their lives as if God existed - veluti si Deus daretur. ${ }^{42}$ Thanks to this, nobody would be restricted in their freedom and everyone would receive the criterion and foundation that Europe needs so much.

In this context of the crisis of European identity, the German theologian recalls Benedict of Nursia, whom he, following the example of Abraham, calls the father of many nations. The modern world is looking for people who, by means of rational and existential faith, would make God credible in this world. We need people who will seek God first and foremost, and look to God to learn true humanity from Him, people whose mind will be enlightened by God's light, whose hearts will be touched by God's love. ${ }^{43}$ Such a man was the holy Abbot of Monte Casino, who in times of turmoil and fall, took the path of a lonely monk's life. Patiently following the path of purification upwards, towards the light, towards God, who gave Himself in Jesus Christ, he built a city on the mountain, a monastery, from which our new European world began. The path marked by Saint Benedict is still valid for Europe, it is a path through crises upwards, towards God. ${ }^{44}$ Simultaneously, it is a path to an authentic humanist culture corresponding to human dignity. ${ }^{45}$

Benedict XVI in the encyclical Spe Salvi recalled the brilliant intuition of Saint Bernard of Clairvaux. According to him, monks who close behind the walls of the monastery do not run away from the world, and especially from responsibility for it. On the contrary, they commit themselves to the whole Church and, consequently, also to the world. The ones who contemplate God become farmers cultivating the world. In fact Bernard explicitly states that not even the monastery can restore Paradise, but he maintains that, as a place of practical and spiritual "tilling the soil", it must prepare the new Paradise. A wild plot of forest land is rendered fertile - and in the process, the trees of pride are felled, whatever weeds may be growing inside souls are pulled up, and the ground is thereby prepared so that bread for body and soul can flourish "the monastery, as it were, a place where the earth is plowed and the spirit is shaped, is to prepare a new paradise. The wild forest area becomes a fertile ground when pride trees are brought down, when the

${ }^{42}$ See ibidem, p. 71.

${ }^{43}$ See J. Szymik, Prawda i madrość..., pp. 163-167; R. Regoli, Benedykt XVI..., pp. 322-326.

${ }^{44}$ See R. Skrzypczak, Książka na trudne czasy [in:] R. Dreher, Opcja Benedykta XVI, Kraków 2018, pp. 9-16.

${ }^{45}$ See J. Szymik, Prawda i mądrość..., pp. 183-185. 
wild in the soul is uprooted, and in this way an area is prepared in which bread for the body and the soul can grow" ${ }^{46}$ Above all, looking for God, sensitizing us to the need to seek the truth, showing the paths of freedom seeking good and beauty, is the mission of Christians in the modern world, and at the same time, a necessary condition for integral humanism and the creative development of European culture. Saints, often nameless, change the world. It is humanized primarily by human change, not by changing social structures. Jesus Christ is the savior of man as a person, not the world's fixer. It is not knowledge or technology that saves, although they undoubtedly make life more efficient and better, but truly free love, in accordance with the incarnate Word. This is a task that every young generation of Europeans must undertake over and over again.

\section{Summary}

Josef Ratzinger has made the problem of the solid foundations of European humanism one of the most important in his scientific and pastoral work. Called to the Holy See, he chose the name Benedict XVI, indicating the Saint Abbot of Nursia as the special patron of his pontificate. In this study two valuable statements of Pope Ratzinger are discussed, showing the relationship between European humanism and Benedictine monasticism. The first is the speech of Benedict XVI during a meeting with people active in culture at the Bernardine College in Paris on September 12, 2008. The second is the text Crisis of cultures, in which the Pope pensioner presents Abbot Benedict and his way of life as an adequate response to the contemporary crisis of European humanism. To seek God in the first place, to sensitize conscience to trueness, showing the paths of freedom, which advocates good and beauty, is the calling of Benedictine monks and at the same time, a necessary condition for integral humanism, the creative development of European culture.

\section{Keywords}

Benedict XVI, humanism, monasticism, European culture, Saint Benedict of Nursia

\section{Europejski humanizm a benedyktyński monastycyzm. Wokól wybranych wypowiedzi Benedykta XVI}

\section{Streszczenie}

Josef Ratzinger problem trwałych fundamentów europejskiego humanizmu uczynił jednym z najważniejszych w swojej pracy naukowej i duszpasterskiej. Powołany na Stolicę Piotrową wybrał

${ }^{46}$ Benedict XVI, Encyclical letter "Spe salvi”, Cracow 2007, http://www.vatican.va/content/ benedict-xvi/en/encyclicals/documents/hf_ben-xvi_enc_20071130_spe-salvi.html2007, [accessed 30.09.2020] p. 15. 
imię Benedykta XVI, wskazując świętego Opata z Nursji jako szczególnego patrona swojego pontyfikatu. W opracowaniu omówiono dwie cenne wypowiedzi papieża Ratzingera ukazujące relacje pomiędzy europejskim humanizmem a benedyktyńskim monastycyzmem. Pierwszą z nich jest przemówienie Benedykta XVI wygłoszone w czasie spotkania z ludźmi kultury w Kolegium Bernardynów w Paryżu 12 września 2008 r. Drugą jest tekst Kryzys kultur, w którym papież emeryt przedstawia opata Benedykta i jego sposób życia jako adekwatną odpowiedź na współczesny kryzys humanizmu europejskiego. Poszukiwać na pierwszym miejscu Boga, uwrażliwiać sumienia na wierność prawdzie, wskazywać drogi wolności, która opowiada się za dobrem i pięknem, to powołanie benedyktyńskich mnichów a zarazem konieczny warunek integralnego humanizmu, twórczego rozwoju kultury europejskiej.

\section{Słowa kluczowe}

Benedykt XVI, humanizm, monastycyzm, kultura europejska, św. Benedykt z Nursji

\section{References}

Benedict XVI, Encyclical letter “Spe salvi”, Cracow 2007, http://www.vatican.va/content/ benedict-xvi/en/encyclicals/documents/hf_ben-xvi_enc_20071130_spe-salvi.html.

Benedykt XVI, Fundamentem prawdziwej kultury jest poszukiwanie Boga (Paris 12 September 2008), "L'Osservatore Romano" (Polish edition) 10-11 (2008), pp. 12-16.

Benedykt XVI, Mistrzowie duchowi. Ojcowie i pisarze średniowiecza, Poznań 2011 [translation after Polish version of L'Osservatore Romano].

Benedykt XVI, Mistrzowie franciszkańscy i dominikańscy, Poznań 2012 [translation after Polish version of L'Osservatore Romano].

Benedykt XVI, Mistrzynie duchowe, Poznań 2012 [translation after Polish version of L'Osservatore Romano].

Benedykt XVI, Niczego nie przedkładać nad miłość Chrystusa (Monte Casino 24 May 2009), "L'Osservatore Romano" (Polish edition) 9 (2008), pp. 52-53.

Bogaty wiarą i człowieczeństwem, "Przewodnik katolicki” 33 (2009), p. 27.

Bürkle H., Człowiek w poszukiwaniu Boga, tłum. M.E. Kowalska, Poznań 1998.

Guerriero E., Świadek prawdy. Biografia Benedykta XVI, thum. J. Tomaszek, Kraków 2018.

Kiejkowski P., Czy nauka może zastapić wiarę? Relacja między wiara a nauka w tekstach Josepha Ratzingera (Benedykta XVI) [in:] Wiara pod lupa. Współczesne pytania o racjonalność wiary, red. R. Pietkiewicz, Wrocław 2014, pp. 147-168.

Kijas Z.J., Poczatki świata i człowieka, Kraków 2004.

Nichols A., Myśl Benedykta XVI Wprowadzenie do myśli teologicznej Josepha Ratzingera, tłum. D. Chabrajska, Kraków 2006.

Ratzinger J., Czas przemian w Europie. Miejsce Kościoła i świata, tłum. M. Mijalska, Kraków 2005.

Ratzinger J., Europa Benedykta w kryzysie kultur, tłum. W. Dzieża, Częstochowa 2005. 
Ratzinger J., Ku ,, dojrzałości” wiaryw Chrystusa (Vatican, 14 April 2005), “L'Osservatore Romano" (Polish edition) 6 (2005), pp. 29-30.

Regoli R., Benedykt XVI wielki papież czasu kryzysu, tłum. K. Dyjas-Fezzi, Kraków 2017. Seewald P., Benedykt XVI. Portret z bliska, tłum. G. Popek, Kraków 2006.

Seweryniak H., Świadectwo i sens, Płock 2001.

Skrzypczak R., Książka na trudne czasy [in:] R. Dreher, Opcja Benedykta. Jak przetrwać czas neopogaństwa?, tłum. M. Samborska, Kraków 2018, pp. 9-16.

Szymik J., Prawda i mąrość. Przewodnik po myśli Benedykta XVI, Kraków 2019.

Szymik J., Theologia Benedicta, t. 2, Katowice 2010.

Vatican Council II, Pastoral Constitution on the Church in the Modern World: Gaudium et spes, http://www.vatican.va/archive/hist_councils/ii_vatican_council/documents/ vat-ii_const_19651207_gaudium-et-spes_en.html.

Weigel G., Benedetto XVI. La scelta di Dio, Soveria Mannelli 2016.

Wencel K., Traktat o człowieku [in:] Dogmatyka, red. A. Adamiak, A. Czaja, J. Majewski, t. 5, Warszawa 2007, pp. 15-212. 